The period of revolution is $2434^{\circ} 2$ days, or 6.664 years, therefore nearly identical with that of Biela's comet up to 1852. The comet passed its perihelion on May 10 . It will not arrive at its Icast cistance from the earth until October 20 , but the theoretical intensity of light climinishes from the present time, inceed has been on the decrease since the middle of May; the come: may be a test object on the borders of the constellations Erionanus and Orion in September and October.

It is probable that this comet had been revolving in its present restricted orbit for many years previous to its discovery in June, I851. It certainly cloes not furnish a parallel case to that of Brorsen's comet, which was detected at its first perihelion passage after the attraction of the planet Jupiter had impressed upon it the actual form of orbit in May I842. The nearest approach of D'Arrest's comet to Jupiter during the revolution immediately precocliner discovery, took place at the end of September $18+9$, when the distance was I'I 36 .

THE BINARY STAR a CENTAURI.-Mr. Ellery communicates to the Royal Astroncmical Society recent mcasures of this, the finest and most interesting of all the revolving double-stars. Taking means the following epochs result from t\} $\mathrm{c}$ Melbourne measures :-

$$
\begin{array}{ccccc}
187672 & \text { Pusition } & 51 \cdot 1 & \text { Distance } & 4 " 3 \\
1877.25 & , & 69.1 & , & 3 \cdot 13
\end{array}
$$

Mr. Maxwell Hall (NATCRE, vol. xv. p. 510 ) supplies the following :-

$$
\text { I } 877 \cdot 14 \text { P'osition } 64 \% 4 \text { Distance } 3^{\prime \prime} \cdot 3
$$

Mr. Ellery states that the distance in I 862 was $10^{\prime \prime}$, but this must be an over-estimate with the meridian instrument; a mean of seventy micrometrical measures by Nr. Eyre B. Powell at Madras, sives for $1862 \%$, a distance of only $6^{\prime \prime} 79$, a result no doubt entitled to great conticience. The first minimum of distance appears tu hate occurred in 1856 . Capt. Jacob's measures for I 856.27 giving $3^{\prime \prime} \cdot 89$, and a maximum of about $10^{\prime}$ followed in I $865-70$. It is to be hoped that the star will now be frequently measured micrometrically with all possible prccision, though the brilliancy and closeness of the components may render such measures difficult. A practised computer should be abie to throw some light on the real nature of the orbit from the data already in our possession, but the continued regular measurement of the star at this critical period cannot fail to be of great importance in extending our knowledge of the motion in this system. The reliable estimate of its distance resulting from the observations of Henderson, Maclear, and Moesta, vastly increases the interest attaching to it.

\section{GEOLOGICAL NOTES}

GeOlogical SURVEY OF THE UNITED Kingdom.-The gradual progress of the English and Scottish Geological Surveys has brought the members of the two corps almost within sight of each other. The line of demarcation between the two kingdoms being nearer the base of operations from Scotland, has been sooner reached from that side. From Berwick-on-Tweed southwestwards the work has been carried up from the north to the English border through the range of the Cheviot Hills, and down the valley of Liddesdale to the Solway. To prevent any subsequent risk of the lines from either side not fitting accurately, the officers on the Scottish border are at present engaged in running their boundaries into Cumberland and Northumberland for such a siort distance as may be required to leave them in a position where they can be easily taken up by the advanced guard of the English Survey. When this and some few isolated areas are completed, the whole of the south of Scotland between the Tay and Clyde and the English border will have been geologically surveyed, and the Scottish staff will then be engaged on both sides of the flanks of the
Highlands. Already ground has been broken, and some progress has been made on the north side of the Grampian chain. On the English side the mountainous lake district is all surveyed, while the work is so well advanced in Cumberland that it may probably be completed up to the Scottish border by the end of this year. Considerabie progress has likewise recently been made on the eastern side in pushing the survey northwards in Northumberland, though a considerable tract of that country still remains unmapped towards the Cheviots and I weed. Among the south-enstern counties the survey is advancing. through Norfolk, Suffolk, and Cambriclgeshire, while in the south-west some of the maps which were made in the carly days of the Geological Survey are being re-surveyed and brought up to date in West Somerset and Devon.

Grological Survey of Caindi.--The Report of this Survey for 1875.76 has just arrived. In size, general interest, and geological value, it fully equals its wcllknown predecessors, while in regard to maps, sections, and other illustrations, it even surpasses them. Briefly told, its story is this-The Philadelphia Exhibition absorbed much of the time and thought which would otherwise have been expended on the field-work, laboratory, and muscum duties of the officers. But the director need not resret this temporary suspension of the usual operations of his staff, for there can be no doubt that the display of rocks, minerals, and fossils, made by Canads at the Centennial Exhibition, so universally almired brought the mineral resources of the dominion and the skill of its reological survey before the world with such prominence as could hardly have been attained even with the ablest maps and memoirs. Mr. Selwyn's own labours from April to November, 1875 , embraced an exploration of parts of British Columbia where likewise Mr. George M. Ditwson, who has lately been appointed to the Canadian Survey, has been actively employed. Prof. Macour, besides his geological work, made a careful botanical survey of the rcgion traversed, and his detailed narrative appears in this Report. Mr. Ellis was sent into the Northwest Territory to make a series of borings. Mr: Bell explored the country between James Bay and Lakes Superior and Huron; while in the eastern parts of the Dominion detailed surveys were made in the coal-fields of Nova Scotia, in New Brunswick, and in Cape Breton. Besides these explorations others were continued by $\mathrm{Mr}$. Vennor in Ontario. Of these Mr. Selwyn remarks that they prove the existence in Western Quebec and Eastern ()ntario of a massive red orthoclase gneiss without visible stratification, lying probably unconformably under the vast crystalline masses containiny Eozoon. He suggests that what is called Lower Laurentian may have to be termed Middle, the fundamental red gneiss becoming the Lower.

EXCREMENTITIOUS DEPOSITS IN THE ROCKY MOUNTAINS.-A recent paper to the Philadelphia Academy by $\mathrm{Mr}$. Henshaw, on the excrementitious deposits in the Rocky Mountain region, sustains Prof. Cope's view that they were made by big-eared rats, a species of Neotoma, probably $N$. cinerea. They consist of vegetable matter, sometimes with a bitumen-like look, and varying from this appearance to that of pill-like excrements. In a crevice of the rocks one deposit had a depth of two feet, and contained also some small twigs and "birds" feathers. "The mass was evidently the accumulation of years, and had served as a nest. Throughout was a large amount of hard droppings from which the urine had passed, and whose nature was unmistakable. The urine, charged with a certain amount of excrementitious matters, had filtered through to form the singular deposits." Water or the urine has carried the portions it could dissolve down the faces of walls, and deposited it on shelves where no animals without wings could reach, and sometimes on the roofs of cavities. All the regions where these deposits occur are inhabited by the Neotoma, which is essentially a vegetarian. 